Abanda, F., Manjia, M., Enongene, K., Tah, J. and Pettang, C. (2016) 'A feasibility study of a residential photovoltaic system in Cameroon', Sustainable Energy Technologies and Assessments, 17, pp. 38-49.

DOI: https://doi.org/10.1016/j.seta.2016.08.002

This document is the authors' Accepted Manuscript.

License: https://creativecommons.org/licenses/by-nc-nd/4.0

Available from RADAR: https://radar.brookes.ac.uk/radar/items/95b6ba11-d5ef-4f78-a9ae-e86bc1ea05e5/1/

Copyright (C) and Moral Rights are retained by the author(s) and/ or other copyright owners unless otherwise waved in a license stated or linked to above. A copy can be downloaded for personal non-commercial research or study, without prior permission or charge. This item cannot be reproduced or quoted extensively from without first obtaining permission in writing from the copyright holder(s). The content must not be changed in any way or sold commercially in any format or medium without the formal permission of the copyright holders. 


\title{
A feasibility study of a residential photovoltaic system in Cameroon
}

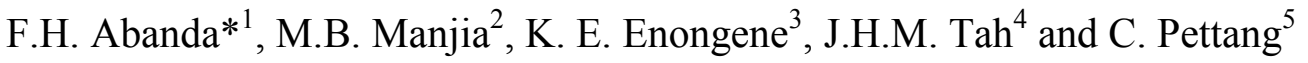 \\ ${ }^{1,4}$ Oxford Institute for Sustainable Development, School of the Built Environment, Oxford Brookes \\ University, Oxford OX3 OBP, UK \\ 2,5 Department of Civil Engineering, National Advanced School of Engineering, the University of \\ Yaoundé I; PO Box. 8390, Yaoundé, Cameroon \\ ${ }^{3}$ Institute of Agriculture and Environment, College of Sciences, Massey University, Palmerston North \\ 4410, New Zealand
}

*Corresponding author: fabanda@,brookes.ac.uk

\begin{abstract}
This paper presents a feasibility study of stand-alone solar photovoltaic (PV) systems for the electrification of three residential case study buildings (T4, T5 and T6) in the capital city of Yaoundé, Cameroon. The system was sized taking into account the load of the buildings and the available energy from the sun. The power, area of PV modules and daily energy generated by the PV for T4, T5 and T6 were respectively determined as: $2103 \mathrm{~W}, 14 \mathrm{~m}^{2}$ and $9.8 \mathrm{kWh} /$ day; $3779 \mathrm{~W}, 25.2 \mathrm{~m}^{2}$ and $17.6 \mathrm{kWh} /$ day; and $2766 \mathrm{~W}, 18.4 \mathrm{~m}^{2}$ and $12.9 \mathrm{kWh} /$ day. The battery bank capacity, size of inverter and controller were respectively obtained as: 40 $323 \mathrm{Wh}, 635 \mathrm{~W}$ and $93 \mathrm{~A}$ for T4; 72 433Wh, 795W and 156A for T5; and $53017 \mathrm{Wh}, 826 \mathrm{~W}$ and 114A for T6. The life cycle cost and annualized life cycle cost (ALCC) of the systems were respectively found to be: $€ 15714$ and $€ 1039$ for T4; $€ 27227$ and $€ 1800$ for T5; and $€ 20006$ and $€ 1322$ for T6. The average unit electricity cost for T4, T5 and T6 was respectively determined to be $€ 0.52 \mathrm{~kW} \mathrm{~h}^{-1}, € 0.50 \mathrm{~kW} \mathrm{~h}^{-1}$ and $€ 0.51 \mathrm{~kW} \mathrm{~h}^{-1}$, higher than the unit cost of residential grid electricity in Cameroon.
\end{abstract}

Key words: Building energy efficiency, Energy, Fuel poverty, PV-systems, residential buildings 


\section{Background}

Greenhouse gas $(\mathrm{GHG})^{1}$ emissions emanating from anthropogenic and natural activities since the onset of the industrial age have led to their increased concentration in the atmosphere. The absorption of radiations by these gases alters the amount of solar radiation reaching the earth and the amount of infrared radiation that goes into space. The result is the disruption of the earth-atmosphere energy balance leading to cooling or warming of the climate depending on the radiating forcing being negative or positive (Forster et al., 2007). The change in the global climatic parameters have in recent times raised serious global concerns and is currently one of the most worrisome problem faced by the contemporary world. Energy security is yet another issue of global concern precipitated by the unprecedented depletion of oil wells and a concomitant increase in the demand of energy to drive national economies (Charman, 2010). The built environment is recognised for its high energy use. As reported by the IPCC (2014), the global building sector accounted for about $32 \%$ of final energy use and over $8.8 \mathrm{GtCO}_{2}$ emissions in 2010 , with energy demand from this sector projected to double by mid-century. The consumption of energy by this sector is not without environmental impacts (Saidi and Hammami 2015) and implications on security of energy supply (Ang et al., 2015). The impacts of conventional or fossil energy sources coupled with recent reduction in cost has led to an increase in the demand of PV-systems in most countries. It is now common to find that small scale PV-systems installed on rooftop for the onsite generation and use of electricity in buildings is cost competitive compared to electricity generated from conventional power plants (Rodrigues et al., 2016). This is the case for countries like: Germany and India which proved to be the best of 16 countries for the investment of a $1 \mathrm{KW}$ PV-system; and Italy and the United States which are the best countries for the investment of a $5 \mathrm{KW} \mathrm{PV-system} \mathrm{out} \mathrm{of} 16$ countries. In some parts of Africa like Kenya, the high connection cost to the grid, unreliability of grid supply and corruption has resulted in many financially viable individuals to shun the national grid and resort to the use of solar home systems to meet their electricity needs (Opiyo, 2016). It is anticipated that once 100\% electrification rate is achieved in the Kendu Bay of Kenya, only $26 \%$ of residents will have their energy needs met by the national grid alone while $38 \%$ will be electrified through PVbased communal grids, $36 \%$ through PV home systems and communal grids. However, while PV-system costs have witnessed a decrease globally, the prevailing PV-system cost in Sub Sahara Africa is much higher when compared to the world average and this could be attributed to the political, financial and technological risks (Baurzhan and Jenkins, 2016).. Despite this, in developing countries, PV-systems provide a solution to electricity especially in areas with lack of access to the grid (Zubi et al., 2016). In Tunisia for instance, hybrid renewable energy system applications that entails solar and wind is considered a viable option for meeting high electricity demands (Maatallah et al., 2016).

In Cameroon, the residential sector is the second highest electrical energy consumer after the industrial sector, accounting for 30\% of total energy consumed (European Union Energy Initiative Partnership Dialogue Facility, 2014). The building sector constitutes an important developmental sector in Cameroon through its role in the provision of shelter and

\footnotetext{
${ }^{1}$ All other abbreviations have been included in Appendix III
} 
contribution to economic growth (Yemene, 2009). This sector has grown tremendously, boosted by the housing boom and public construction sites observed in recent times. Based on the International Futures statistics (http://www.ifs.du.edu/ifs/frm_CountryProfile.aspx?Country=CM), the population of Cameroon is projected to increase from 23.22 million in 2015 to 32.96 million in 2030 . Hence, to cater for this expected population increase, the expansion or growth of housing sector is imperative. The expected increase in housing will put pressure on the country's energy infrastructure which currently, is inadequate in meeting the nation's electricity demand. This is further exacerbated by the low rates of electrification and access to the electricity grid (Ayompe and Duffy, 2014). Improvement in energy efficiency and the employment of renewable energy technologies in buildings play an important role in reducing energy demand and GHG intensity (Girod, et al., 2014). Other than the role of renewable energy in climate change mitigation, they are important in meeting the basic energy needs (heating and lighting among others) of communities thereby contributing to the alleviation of energy poverty which in turn reduces economic poverty (Lillo et al., 2015). Energy poverty refers to the "absence in sufficient choice in accessing adequate, affordable, reliable, high-quality, safe and environmentally benign energy services to support economic and human development" (Reddy, 2000).

Energy use in buildings constitutes a large part of energy demand at the global and regional levels (Ürge-Vorsatz, 2015) contributing a major share to global environmental concerns (Ürge-Vorsatz, 2013). Environmental pressures related to the quality and quantity of energy consumed in buildings includes energy insecurity, indoor and outdoor air pollution and related health risks and damages. The consumption of energy in buildings has consequences that impede the attainment of sustainable development goals (Ürge-Vorsatz, 2015). Such consequences include among others deaths attributed to the use of traditional energy sources like fuel wood for indoor cooking, lack of access to modern energy services for all, and inadequate energy resources to fuel economic growth. The efficient use of energy in buildings is yet another issue of global concern. Low-income households often have high energy cost as result of poor structural conditions and energy inefficiency in their dwellings (Hernández, 2015). Energy inefficiency in buildings results in excessive consumption of energy therein putting pressure on the grid electricity supply which is often generated from conventional fuel associated with GHG emission that drives global climate change. The deployment and integration of renewable energy technologies into buildings and the existing energy infrastructure have potentials to lessen climate change through the reduction in GHG emissions. So far, efforts to assess renewable energy potential in Cameroon have largely been descriptive (Abanda, 2012; Abanda et al., 2012; Wirba et al., 2015). Based on the literature review, very few studies have examined the feasibility of renewable technologies in Cameroon. Nfah et al. (2007) investigated the technical feasibility of solar/diesel/battery hybrid power systems for the electrification of rural households in the Far-North region of Cameroon. Nfah (2013) conducted an economic analysis of photovoltaic hybrid systems for remote villages in Far-North of Cameroon. Nfah and Ngundam (2008) investigated the technical feasibility of wind/diesel/battery hybrid power systems for Far-North Cameroon. Mbaka et al. (2010) conducted an economic assessment of different types of PV-systems by 
comparing the net present value (NPV) between photovoltaic hybrid systems (PVHS), standalone photovoltaic (PV) and standalone diesel generator options. While these studies have been detailed on an either technical or economic feasibility, there are limited in scope and failed to take into account simultaneously the technical, environmental as well as economic dimension. Furthermore, the studies often assess only the PV-array without including significant components such as battery, charge controller and inverters. In Nfah and Ngundam (2008), the effect of battery systems has not been investigated as well as the unit cost of energy produced by the wind/diesel system (Nfah and Ngundam, 2008). In Nfah et al. (2007), an economic analysis of power supply options involving grid extension, a conventional diesel generator plant, and solar/diesel/battery hybrid power system was not considered for the feasibility study in the Far-North of Cameroon.

The aim of this study is to conduct the technical, environmental and economic feasibilities of residential buildings in Cameroon. The inclusion of the technical, environmental and economic dimensions in this study is novel, given most studies have often considered one or at most two dimensions as discussed in the preceding paragraph. Another novelty is the consideration of four PV-system components: PV-module, battery, charge controller and inverter in the assessment. Most studies usually consider only the PV-module because of its large size and the fact that it is the component directly in contact with the external environment. Three dwellings, representing typical homes in Cameroon will be employed as cases for the assessment.

\section{Energy use in Cameroon}

The energy production in the country in 2010 was estimated at 8521 kilotonne of oil equivalent (ktoe) of which biomass, oil and electricity contributed 53\%, 42.7\% and 4.3\% respectively (SIE-Cameroun, 2012). In 2012, electricity contributed only 7\% to the country's energy demand (International Energy Agency, 2015). Cameroon's final energy consumption per capita in 2010 was 0.12 toe (United Nations Statistics Division, 2015), below the African and world average of 0.49 and 1.26 respectively. The supply of electricity, which plays an unequivocal role in the growth of any modern economy by virtue of its diverse end uses is inadequate in the country, exacerbated by the frequent power cuts mostly experienced during the months of January to June (Nfah and Ngundam, 2009). During the period of drought, the output power generated by back-up thermal plants is usually insufficient to meet demand and the rationing of electricity does not guarantee the day-to-day operation of industries especially those connected to networks of low voltage. Regarding electricity access in the country, about 3000 out of 14000 localities are electrified amounting to a national electrification rate of 22\% while rural electrification rate stands at 3.5\% (Ayompe and Duffy, 2014). This low access to electricity especially in the rural areas of the country where the situation is acute implies that the population in these areas rely on traditional energy sources and appliances like fuel wood and kerosene lamp respectively to meet their basic energy needs. The use of fuel wood does not only results to indoor air pollution that causes respiratory diseases but its extraction culminates in the degradation of the nation's forest resources (Government of Cameroon, 2013) which contributes to climate change, with the Northern Region of the country already under the likelihood of experiencing desertification. 
This prevalence of energy poverty in the country contributes to economic poverty since the lack of access to modern energy actually limits the capacity of the energy poor to embark on income generating activities, making it difficult for them to come out of poverty. According to the Government of Cameroon's Growth and Development Strategy Paper (Government of Cameroon, 2009), this structural weakness that rocks the energy sector of the country has resulted to the slow economic growth witnessed over time. To this end, the government of Cameroon is committed to tripling the electricity production capacity of the country from 2020-2025 in order to boost domestic supply and to become an electricity exporter (SIECameroon, 2012).

Data about solar energy reaching surfaces in Cameroon slightly varies with respect to different regions. According to Ayompe and Duffy (2014), Cameroon is endowed with a huge solar potential with an estimated 900 trillion $\mathrm{kWh}$ of solar energy that reaches it land surface per year. A more recent study by Mboumboue and Njomo (2016) reveals that the global solar radiation received in Cameroon varies between $2.9052 \mathrm{kWh} / \mathrm{m} 2 /$ day and 4.9709 $\mathrm{kWh} / \mathrm{m} 2 /$ day for Yaoundé, $3.1159 \mathrm{kWh} / \mathrm{m} 2 /$ day and $6.2602 \mathrm{kWh} / \mathrm{m} 2 /$ day for Garoua, 2.8535 $\mathrm{kWh} / \mathrm{m} 2 /$ day and $5.9245 \mathrm{kWh} / \mathrm{m} 2 /$ day for Bamenda and $3.2024 \mathrm{kWh} / \mathrm{m} 2 /$ day and 5.9788 $\mathrm{kWh} / \mathrm{m} 2 /$ day for Bertoua. The national average of solar radiation received in Cameroon in a year stands at $4.2824 \mathrm{kWh} / \mathrm{m} 2 /$ day. Given the countries surface area is $475442 \mathrm{Km} 2$, therefore the total solar potential in Cameroon is $4.2824 \mathrm{kWh} / \mathrm{m} 2 /$ day * 475442000000 $\mathrm{m} 2 * 365$ days $=7.432 \times 10^{8} \mathrm{GWh}$ per year. This solar potential of $7.43210^{8} \mathrm{GWh}$ per year, representing 127382.9 times the total electricity production of Cameroon estimated at 5834 GWh by the Africa-EU energy Partnership (undated). This demonstrates Cameroon has a great amount of solar resources that can be exploited for the benefit of the population. Some of the uses or benefits include the use of solar power in the provision of street lighting and in powering base transceiver stations of mobile telephone network companies. Recent examples of solar powered street lighting can be seen in the streets of the city of Yaoundé (Wirba et al., 2015).

\section{An overview of PV technology}

The solar PV-system generates direct current electricity from solar radiation (Oshaba and Ali, 2014) through the photovoltaic effect. At the heart of the entire PV-system is the solar module which is usually composed of several individual cells whose number and arrangement in the module determines the energy produced by the PV-system (Zeman, 2012; Rehman, et. al., 2007). Also, PV modules can be arranged in an array so as to generate a specific voltage and current. For some PV-systems that need to function at night and under bad weather conditions, batteries for electricity storage are an important and indispensable component. Electricity generated from PV-systems can be fed directly to the grid, electrical load or to batteries. The energy generated by the PV module is determined by the intensity of sunlight and the temperature of the cell. The charge controller regulates the DC current output that is delivered to the grid, load or battery by switching off the PV module when the battery is fully charged. In some PV applications, a maximum power point tracker (MPPT) is used to maximise the output of the system (Oshaba et al., 2015). In order for the generated 
current to be used for alternating current applications, DC/AC inverters are integrated in the PV system which converts the DC current into AC current (Zeman, 2012).

Based on system configuration, Zeman (2012) distinguishes three basic types of PV-systems: stand-alone, grid connected and hybrid system. The stand-alone PV-system rely only on PV power and can be connected directly to a load or can include batteries for the storage of the generated energy during the day to be used at night or during periods of poor weather conditions. The grid connected systems are used as power stations since the generated power is connected to the grid through inverters and no battery is required for storage. Hybrid systems entails the combination of PV modules and another means of electricity generation including but not limited to gas, wind or diesel generator and often require a more sophisticated control compared to the stand-alone PV-systems. The stand-alone solar PVsystems are the most predominantly used in Cameroon. In some circumstances, batteries are used as back-up systems for stand-alone systems. Other than for residential lighting, standalone solar systems are now being used in street lighting in cities like Buea and Yaoundé.This study focuses on the use of a stand-alone PV system (see Figure 1) to meet the energy needs of a typical building in Cameroon.

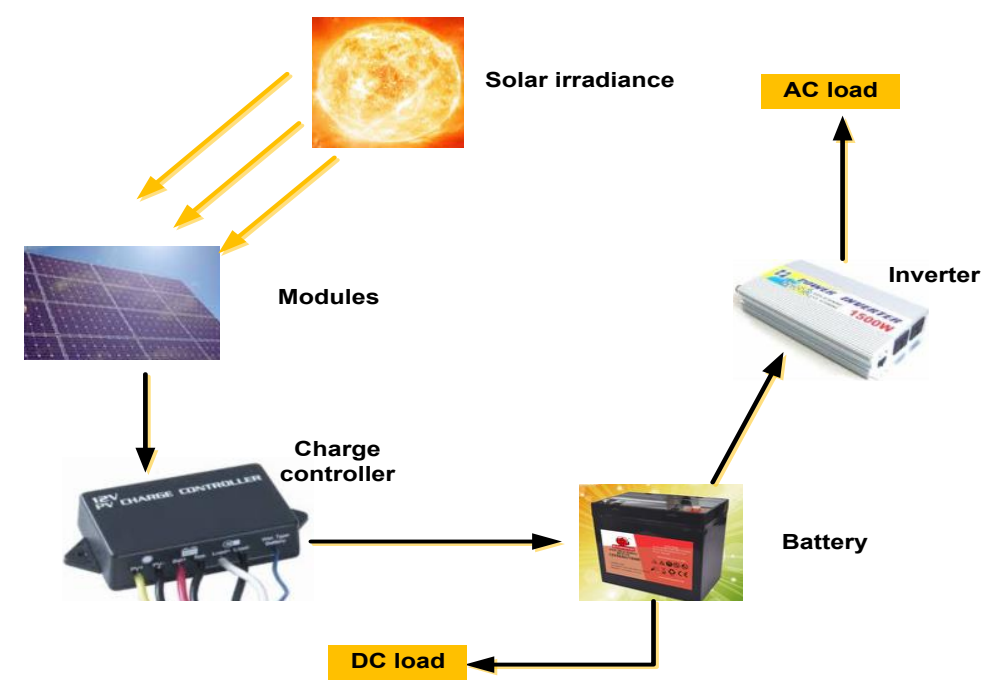

Figure 1: Components of a stand-alone PV system (adapted from Abdul and Anjum, 2015).

\section{Description of case study buildings}

The Cameroon Ministry of Housing and Urban Development classifies residential buildings into six different categories based on the minimal area and components of the building called T1, T2, T3, T4, T5 and T6 (Manjia et al., 2015). However, for purposes of this study T4, T5 and T6 will be considered for this study. This is because they contain significant information about household appliances than T1, T2 and T3 as reported in Manjia et al.(2015). It is assumed that the walls of the T4, T5 and T6 building composed of sand-crete blocks and their roof cover is composed of corrugated zinc sheets (Manjia et al., 2015). Data about housing 
numbers is scarce, hence difficult to state the exact proportions of T1, T2, T3, T4, T5, T6 with respect to the residential stock. However, according to the government data, up to one million homes need to be built in the next five to ten years to adequately house the growing population (CAHF, 2015). It is impossible to know how many of this backlog will be provided by the government. However, the state-owned Cameroon Real Estate Corporation (Société Immobilière du Cameroun, or SIC) aims to build 100000 homes by 2022 (CHA, 2015). These new homes are most likely to be one or a mixture of T1, T2, T3, T4, T5 and/or T6. The characteristics of T1, T2, T3, T4, T5 and T6 are presented in Table 1.

Table 1: Category of residential buildings in Cameroon

\begin{tabular}{|c|c|c|c|c|}
\hline Type & Component & Quantity & $\begin{array}{c}\text { Minimal area } \\
\left(\mathrm{m}^{2}\right) \text { per } \\
\text { component }\end{array}$ & $\begin{array}{c}\text { Total } \\
\text { minimal } \\
\operatorname{area}\left(\mathbf{m}^{2}\right)\end{array}$ \\
\hline \multirow{5}{*}{$\mathrm{T} 4$} & $\begin{array}{l}\text { Living room }+ \\
\text { Dining room }\end{array}$ & 1 & 25 & \multirow{5}{*}{89} \\
\hline & Bedroom & 3 & 12 & \\
\hline & kitchen & 1 & 10 & \\
\hline & Toilet & 2 & 5 & \\
\hline & Corridor & 1 & 8 & \\
\hline \multirow{5}{*}{ T5 } & $\begin{array}{l}\text { Living room }+ \\
\text { Dining room }\end{array}$ & 1 & 30 & \multirow{5}{*}{106} \\
\hline & Bedroom & 4 & 12 & \\
\hline & Kitchen & 1 & 10 & \\
\hline & Toilet & 2 & 5 & \\
\hline & Corridor & 1 & 8 & \\
\hline \multirow{5}{*}{ T6 } & $\begin{array}{l}\text { Living room }+ \\
\text { Dining room }\end{array}$ & 1 & 35 & \multirow{5}{*}{130} \\
\hline & Bedroom & 5 & 12 & \\
\hline & Kitchen & 1 & 10 & \\
\hline & Toilet & 3 & 5 & \\
\hline & Corridor & 1 & 10 & \\
\hline
\end{tabular}

Without loss of generality technical, economic and environmental potential for the T4, T5 and $\mathrm{T} 6$ buildings will be computed. The floor plans of the dwellings are presented in Figures $2,3 \& 4$ 


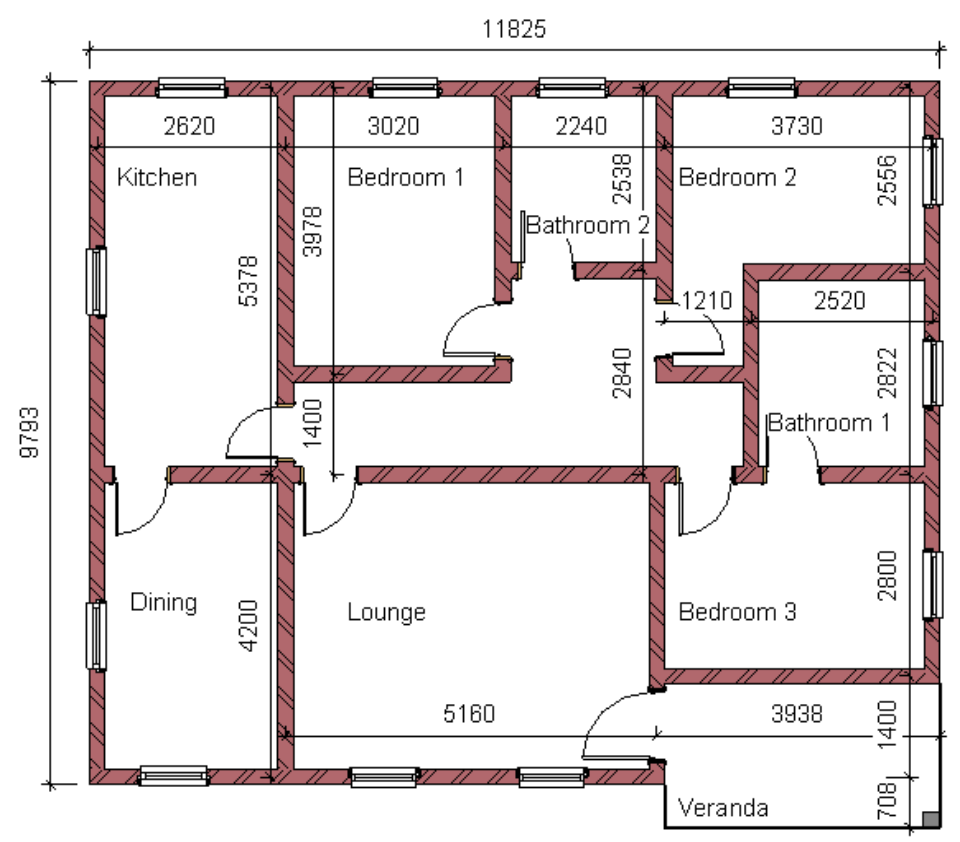

Figure 2: Floor plan of T4 building

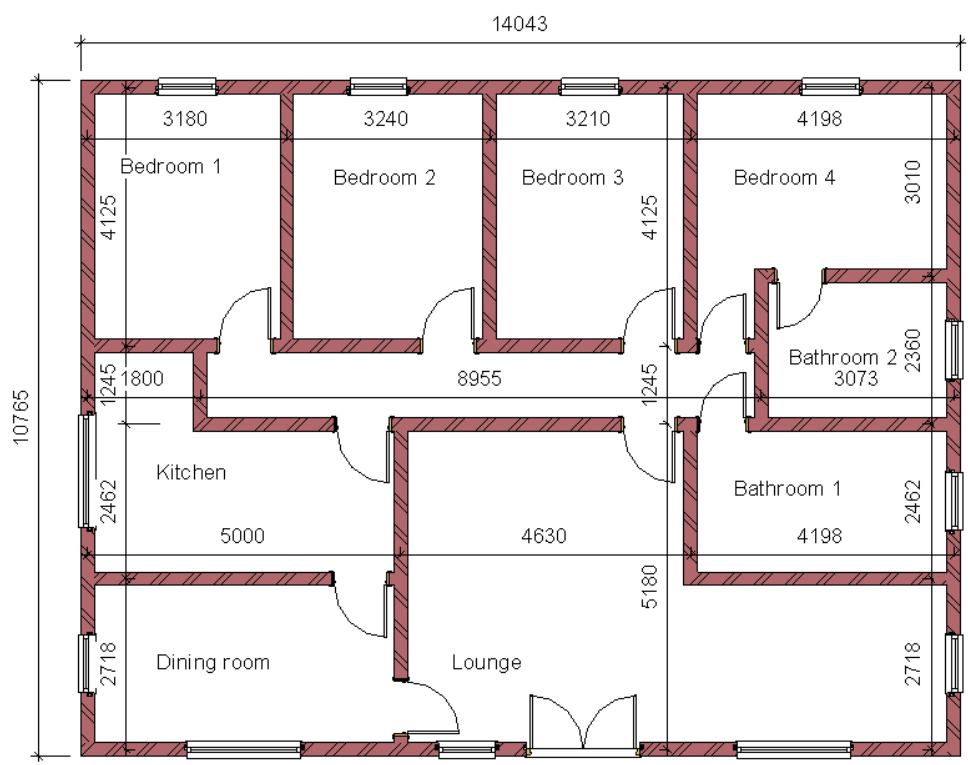

Figure 3: Floor plan of T5 building 


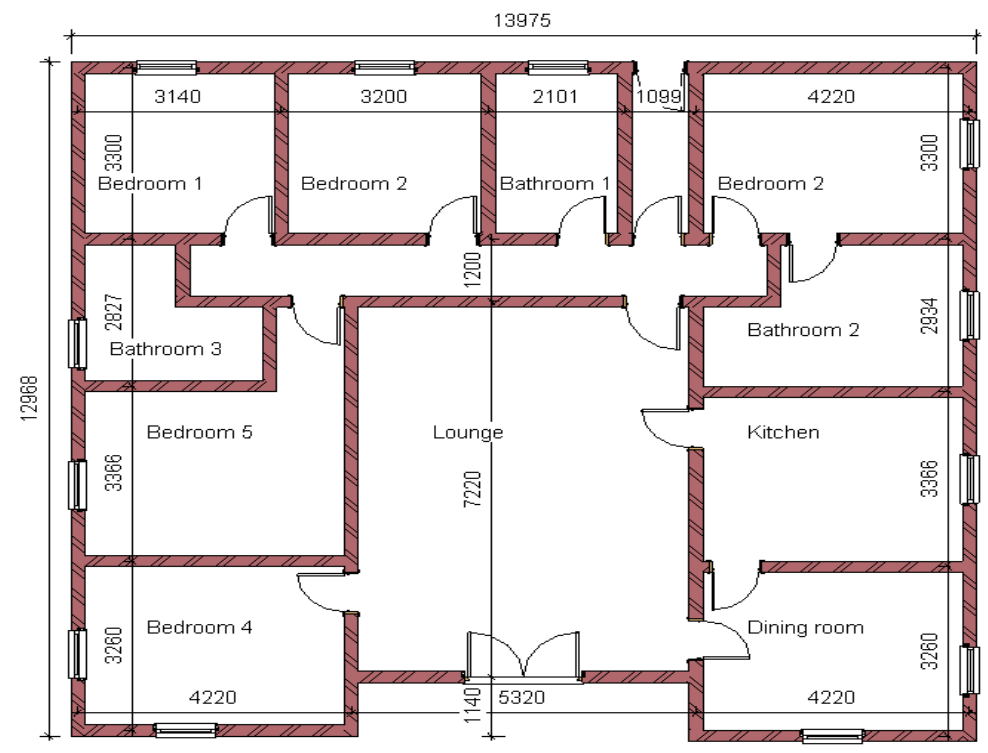

Figure 4: Floor plan of T6 building

In the three case dwellings, the PV-panels are placed on top of the roofs. The maximum space allowed is the dwellings' footprint up to the exterior finishing of the external walls. The installation of the panels cannot extend beyond the external walls as this may not be supported by the roof overhang; unless external columns are designed to act as supports. Based on the floor plans of T4, T5 and T6, the different roof area excluding roof overhangs allowed for the PV-panels are $111.5 \mathrm{~m}^{2}, 151.2 \mathrm{~m}^{2}$ and $176.4 \mathrm{~m}^{2}$ respectively. The detail computation of $\mathrm{T} 6$ will be presented in Appendix I and results for the others will be discussed in the manuscript.

\subsection{Technical Potential}

Determining the technical potential of a PV-system entails determining if the amount of energy it generates can power a giving building. Therefore the energy consumed by the case study buildings is required. The use of energy in a building is determined by a number of factors including but not limited to the number and types of appliances therein (Estiri, 2014; Won and Hong, 2014). As a result of the high cost associated with energy efficient appliances, most households in Cameroon tend to use obsolete and less efficient appliances imported from developed countries (Kenfack et al., 2011). These less efficient appliances are sold by local vendors culminating in a variation in the power rating of some appliances which according to Manjia et al. (2015) could be accounted for by the lack of standardisation of electrical appliances in Cameroon.

\section{Power consumption (kWh) and building load profiles}

The energy consumption pattern of a household is influenced by the number of occupants and their daily activities among other factors. Novoselac et al. (2014) investigated the impact of three factors (energy use on weekdays versus weekends, energy use of households with 
members working at home versus who do not, and energy use during cooling and heating seasons) on the variation in load profiles. The results from the study revealed a correlation between the day of the week and energy use with an increase in energy use and changes in time of use of appliances witnessed over the weekend. The energy load profile for weekdays during business hours (9am-5pm) was found to be low. This is not uncommon since residents work out of their homes and their appliances would not be powered during this time. The weekday load profile for households who work out of home was 2-28\% less than households whose members work from home. The results also revealed a variation in the daily energy load between the cooling and heating seasons but this factor was less influential compared to the other two. A similar energy consumption pattern was observed for Cameroon households by Manjia et al. (2015). Findings from Manjia et al. (2015) revealed that the maximum energy load of the building under study occurred at 6 am while the minimum load occurred between 8 am and $11 \mathrm{am}$. The former coincides with the time occupants prepare to leave the house and therefore would likely have most of their appliances in use while the minimum load occurs when occupants are likely to have left their houses. The daily energy demand of the T6 building type in Yaoundé, Cameroon considered in this study is presented in Table 2.

Table 2. Load of a T6 building

\begin{tabular}{|l|c|c|c|}
\hline Appliance & Power rating (W) & Daily cycle (hours) & Load (Wh) \\
\hline Freezer & 170 & 24 & 4080 \\
\hline Television 1 & 100 & 6 & 600 \\
\hline Television 2 & 130 & 5 & 650 \\
\hline Bulb & 75 & 7 & 525 \\
\hline Laptop & 60 & 2 & 120 \\
\hline Telephone charger & 2 & 7 & 14 \\
\hline Fan & 115 & 9 & 1035 \\
\hline Fluorescent bulb & 36 & 1 & 36 \\
\hline Total & & & $\mathbf{7 0 6 0}$ \\
\hline
\end{tabular}

Source (Manjia et al., 2015)

Based on the assumption that appliances in T5 and T4 buildings in Yaounde have the same daily cycle like the T6 building, the loads of a T5 and T4 building was computed using information from Manjia et al. (2015). The loads for the T5 and T4 building are presented in Table 3 and 4 respectively.

Table 3: Load of a T5 building

\begin{tabular}{|l|c|c|c|}
\hline Appliance & Power rating (W) & Daily cycle (hours) & Load (Wh) \\
\hline Fridge & 300 & 24 & 7200 \\
\hline Television & 57 & 5 & 285 \\
\hline Bulb & 305 & 7 & 2135 \\
\hline Telephone charger & 12.28 & 7 & 85.96 \\
\hline Total & & & $\mathbf{9 7 0 5 . 9 6}$ \\
\hline
\end{tabular}


Table 4: Load of a T4 building

\begin{tabular}{|l|c|c|c|}
\hline Appliance & Power rating (W) & Daily cycle (hours) & Load (Wh) \\
\hline Fridge & 118 & 24 & 2832 \\
\hline Television & 300 & 6 & 1800 \\
\hline Bulb & 75 & 7 & 525 \\
\hline Laptop & 75 & 2 & 150 \\
\hline Telephone charger & 10 & 7 & 70 \\
\hline Fluorescent bulb & 36 & 1 & 36 \\
\hline Total & & & $\mathbf{5 4 1 3}$ \\
\hline
\end{tabular}

Given that the energy consumption values of the case study buildings are now known, in the ensuing paragraphs the design of the PV-system components will be determined. The different components to be designed include the PV-array, battery, controller and the inverter.

\section{The sizing of PV-array}

According to Birajdar et al. (2013), the size of a PV array can be computed using equation 1.

$$
A_{P V}=\frac{L_{e l}}{H_{a v g} \times \eta_{P V} \times \eta_{b} \times \eta_{i} \times T_{C F}}
$$

Where: $A_{P V}$ is the required PV array area in $\mathrm{m}^{2}, \mathrm{~L}_{\mathrm{el}}$ is the required electric load in $\mathrm{kW} \mathrm{h} \mathrm{d}^{-1}$, $\mathrm{H}_{\text {avg }}$ is the average daily irradiation of the location in $\mathrm{kWhm}^{-2} \mathrm{~d}^{-1}, \mathrm{y}_{\mathrm{pv}}$ is the PV panel efficiency in $\%, \mathrm{y}_{b}$ is the battery efficiency, $\mathrm{y}_{\mathrm{i}}$ is the efficiency of the inverter in $\%$ while $\mathrm{T}_{\mathrm{CF}}$ is the temperature correction factor. From Abdul and Anjum (2015), the battery and inverter efficiency is considered to be $85 \%$ and $90 \%$ respectively. The $\mathrm{T}_{\mathrm{CF}}$ was adopted as $80 \%$ from Caisheng and Nehrir (2008).

Since the output of the PV is expected to vary over its lifetime due to degradation, there is need for the PV area to be adjusted taking into account the degradation of the PV. This adjustment is done by dividing the area of the PV by the module derate factor-which accounts for the reduction in the PV output as a result of accumulation of dust and degradation over time. From Sandia National Laboratories (1995), the module derate factor of 0.9 for crystalline module is adopted.

The average daily energy output $(\mathrm{kWh})$ generated by the PV $\left(\mathrm{E}_{\mathrm{o}}\right)$ can be calculated using the average daily solar irradiance and the efficiency of the PV panel as indicated in equation 2.

$$
E_{o}=A_{P V} x H_{\text {avg }} \times \mathrm{\eta}_{P V}
$$

The PV power is then computed by dividing the average daily energy output of the PV by the number of sunshine hours/day.

\section{Sizing of the battery bank}


According to Wenham et al. (1994), the storage capacity of a PV-system battery bank $\left(\mathrm{B}_{\mathrm{SC}}\right)$ is calculated by taking into account the battery efficiency, efficiency of the inverter, depth of discharge of the battery and the system autonomy (number of cloudy days). The formula for determination of the battery size is shown in equation 3.

$$
B_{S C}=\frac{N_{c} \times L_{e l}}{\eta_{B} \times D_{d} \times \eta_{i}}
$$

Where: $D_{d}$ is the maximum depth of discharge of the battery and $N_{c}$ refers to the system autonomy (continuous number of cloudy days). According to NASA surface meteorology and solar energy data available on the NASA website, the highest number of black days (no-sun days) for Yaoundé is 4.57 and this occurs in the month of June. Hence, the battery bank should possess a storage capacity required to provide power for 4.57 days of no sunshine.

\section{Controller Specification}

The function of the charge controller in a system is to ensure safe charging of the battery and consequently eliminating the risk of having the batteries over charged. The controller must have the capacity to handle the maximum current generated by the PV array and its voltage compatible with the nominal voltage of the system. Hence, this device must be sized carefully to ensure that it is able to carry the generated current by the array. The size of the charge controller $\left(\mathrm{S}_{\mathrm{cc}}\right)$ is given by equation 4 .

$$
S_{c c}=\text { Array current } x 1.25
$$

The array current is multiplied by a factor of 1.25 so as to give flexibility to the charge controller to accommodate high current generated by the PV array during period of high irradiance.

\section{Determination of inverter size}

There is need for an inverter to convert the generated DC current into AC current so as to power the AC loads in the building. The inverter should be selected in such a way that it must be able to handle the maximum expected AC power loads (Abdul and Anjum, 2015). Hence, it is recommended for the selected inverter to be $20 \%$ higher than the total rated power of the required AC loads as shown in Table 12 in appendix I.

Using formulas 1-4, the different components of the PV-systems have been computed and presented in Table 6. To facilitate understanding, the computational steps of the sizing of the different components of PV-system for T6 have been presented in Appendix I.

\subsection{Economic Potential}

The economic analysis employed in this study is the life cycle cost analysis (See Appendix II). The life cycle cost analysis of a PV-system embodies the total fixed and operating costs over its life expressed in today's money (Celik, 2006; Ajan et al., 2003; Celik, 2007). The major cost associated with PV-systems includes: the capital cost of the hardware, operation and maintenance cost. Hence, the total life cycle cost of a PV-system is the sum of the 
present worth (PW) of the PV modules, charge controllers, storage batteries, inverter, installation, operation and maintenance cost (Shaahid and Elhadidy, 2008). With the exception of the storage batteries that possesses a life span of 10 years, the PV system is assumed to have a useful service life of 25 years as adopted in other studies by IEA/NEA (2015), Ghosh et al. (2015), Ma et al. (2015), Ayompe and Duffy (2014) and Bouabdallah et al. (2015) among others. Therefore, the batteries needs to be replaced after every ten years and its cost adjusted taking into account inflation (i) and the discount rate (d). The present worth of the different system components were computed as follows:

Cost of PV Array, $\mathrm{C}_{\mathrm{PV}}=$ Unit cost of PV module $\mathrm{x}$ Number of PV modules

Initial cost of batteries $C_{B}=$ Unit cost of battery $x$ Number of batteries

The present worth of $1^{\text {st }}$ and $2^{\text {nd }}$ replacement of the battery after 10 and 20 years respectively was calculated using equation (5).

$$
C_{B 1}=C_{B}\left(\frac{1+i}{1+d}\right)^{n}
$$

Where; $\mathrm{C}_{\mathrm{B} 1}$ is the present worth of battery replaced at year $\mathrm{n}, \mathrm{i}$ and $\mathrm{d}$ represent the inflation and discount rate respectively.

The cost of the charge controller and inverter is calculated by multiplying their unit cost by their respective size. The installation cost of the system is estimated to be $10 \%$ of the initial cost of the PV modules. Using the annual maintenance cost $(\mathrm{M} / \mathrm{yr})$ and the lifetime of the system $(\mathrm{N})$, the present worth of the system maintenance cost $\left(\mathrm{C}_{\mathrm{m}}\right)$ was computed using equation (6).

$$
C_{m}=(M / y r) \times\left(\frac{1+i}{1+d}\right)\left[\frac{1-\left(\frac{1+i}{1+d}\right)^{N}}{1-\left(\frac{1+i}{1+d}\right)}\right]
$$

Using the cost of the PV array $\left(\mathrm{C}_{\mathrm{PV}}\right)$, initial cost of battery $\left(\mathrm{C}_{\mathrm{B}}\right)$, present worth of $1^{\text {st }}$ and $2^{\text {nd }}$ battery replacement cost $\left(\mathrm{C}_{\mathrm{B} 1}\right.$ and $\left.\mathrm{C}_{\mathrm{B} 2}\right)$, cost of charge controller $(\mathrm{Cc})$, inverter cost $\left(\mathrm{C}_{\mathrm{i}}\right)$, installation cost $\left(\mathrm{C}_{\text {inst }}\right)$ and the present worth of the maintenance $\operatorname{cost}\left(\mathrm{C}_{\mathrm{m}}\right)$, the LCC of the PV system was then calculated as shown in equation (7).

$$
L C C=C_{P V}+C_{B}+C_{B 1}+C_{B 2}+C_{C}+C_{i}+C_{\text {inst }}+C_{m}
$$

The annualized LCC (ALCC) of the PV-system in terms of its present value was calculated using equation (8).

$$
A L C C=L C C\left\lfloor\frac{1-\left(\frac{1+i}{1+d}\right)}{1-\left(\frac{1+i}{1+d}\right)^{N}}\right\rfloor
$$


The unit cost of the electricity $\left(\mathrm{UC}_{\mathrm{el}}\right)$ generated by the $\mathrm{PV}$-system was computed using equation (9).

$$
U C_{e l}=\frac{A L C C}{365 L_{e l}}
$$

Where: $\mathrm{L}_{\mathrm{el}}$ refers to the daily electrical load of the building in $\mathrm{kWh}$.

In computing the LCC of the residential PV-system, the following cost data of the system components based on current market prices have been used as presented in Table 5. The inflation and discount rate is taken to be 5\% and 10\% (Ayompe and Duffy, 2014) respectively while the maintenance cost of the system was calculated as $2 \%$ of the initial PV cost as was adopted by Abdul and Anjum (2015).

\section{Data for life cycle cost analysis}

The cost of the PV module considered in this study (in Table 5) was obtained from Haute Energy Systems Ltd, a local supplier of PV components in Cameroon. The cost data is presented in Table 5.

Table 5: Cost data for life cycle analysis

\begin{tabular}{|l|l|}
\hline Description & Value \\
\hline Lifetime of PV system & 25 years \\
\hline Inflation rate (i) & $5 \%$ \\
\hline Discount rate (d) & $10 \%$ \\
\hline Charge controller cost & $8.6 € / \mathrm{A}$ \\
\hline Inverter & $0.25 € / \mathrm{W}$ \\
\hline PV module & $2 € / \mathrm{Wp}$ \\
\hline Battery cost & $2.5 / \mathrm{Ah}$ \\
\hline Battery lifetime & 10 years \\
\hline PV system maintenance cost & $2 \%$ of capital cost of modules \\
\hline System installation cost & $10 \%$ of capital cost of modules \\
\hline
\end{tabular}

The cost data in Table 5 are substituted in the formulae 5-9 and the LCC of the PV-system for T6 is presented in Appendix II. Similarly the LCC for T4 and T5 have been computed and discussed.

\subsection{Environmental Potential}

The environmental model often used to assess the environmental footprints of product or services is the life cycle assessment (LCA). LCA is a methodology employed in the quantification of environmental burdens and impacts associated to the life cycle of a product or service, i.e. from cradle to grave (Treyer and Bauer, 2015). LCA allows the identification of environmental hotspots and unbiased comparison of product or services which meets the same needs. For instance, LCA allows the comparison of the environmental footprints of a $\mathrm{kWh}$ of electricity generated from different sources. The emissions from the designed PV- 
system for the chosen case study will be computed and discussed within the context of emissions from conventional and other renewable energy sources.

The manufacture of photovoltaics is associated with high metal use such as iron ore, nickel, copper and silver (Treyer and Bauer, 2015). Electricity generation from photovoltaics is associated with the release of toxic substances to the environment which occurs during the mining process of the metals. However, emissions generated from PV technologies are small compared to those emanating from conventional technologies (Fthenakis, 2008). The life cycle emission of PV per GWh is far less than that of conventional technologies that generates power using fossil fuel. The life cycle emission of PV-system is influenced by the solar cell material since different materials possess different energy requirements for their manufacture. The life cycle emissions for amorphous, monocrystalline and polycrystalline solar PV systems were estimated to range from 15.6-50 $\mathrm{gCO}_{2 \mathrm{eq}} / \mathrm{kWh}, 44-280 \mathrm{gCO}_{2 \mathrm{eq}} / \mathrm{kWh}$ and 9.4-104 $\mathrm{gCO}_{2 \mathrm{eq}} / \mathrm{kWh}$ respectively (Sherwani et al., 2010).

In order to estimate the LCA emissions of the PV-system employed in this study, there is need for data on LCA emissions of PV-system in Cameroon. Unfortunately, data on LCA for PV systems in Cameroon is scarce. The average value $\left(162 \mathrm{gCO}_{2 \mathrm{eq}} / \mathrm{kWh}\right)$ of the emissions associated to monocrystalline PV system obtained by Sherwani et al. (2010) was adopted. The adopted emission value for the PV generated $\mathrm{kWh}$ of power is very small when compared to the emission associated to the generation of a $\mathrm{kWh}$ of electricity from conventional power system like combined natural gas plant $(350-400 \mathrm{gCO} 2 \mathrm{eq} / \mathrm{kWh})$ and base load power plants powered by oil (be $530 \mathrm{gCO}_{2 \mathrm{eq}} / \mathrm{kWh}$ ). Taking into account the estimated emission of a $\mathrm{kWh}$ of conventional electricity generated in Cameroon $\left(860 \mathrm{gCO}_{2}\right)$, the emission savings $\left(E_{\mathrm{s}}\right)$ associated with the use of a $\mathrm{kWh}$ of electricity generated by the PVsystem was computed as follows:

$$
\begin{aligned}
\mathrm{E}_{\mathrm{S}} & =\mathrm{E}_{\mathrm{c}}-\mathrm{E}_{\mathrm{PV}} \\
& =860 \mathrm{gCO}_{2}-162 \mathrm{gCO}_{2}=698 \mathrm{gCO}_{2}
\end{aligned}
$$

Where: $E_{c}$ is the emission associated with a $\mathrm{kWh}$ of conventional generated electricity in Cameroon and $\mathrm{E}_{\mathrm{PV}}$ represents emissions associated with a kWh of PV generated electricity.

Hence, the daily emission savings associated with the use of PV generated electricity in our case study buildings was computed by simply multiplying the daily load (in $\mathrm{kWh}$ ) of the respective buildings by $698 \mathrm{gCO}_{2}$. Accordingly, the daily emissions savings for the $\mathrm{T} 4$, $\mathrm{T} 5$ and T6 building considered in this study are $3769.2 \mathrm{gCO}_{2}, 6770.6 \mathrm{gCO}_{2}$, and $4955.8 \mathrm{gCO}_{2}$ respectively.

Published LCA results for renewable energy technology vary significantly and this leads to confusion pertaining to the actual environmental impact that ensues from the implementation of a renewable energy project (Asdrubali et al., 2015). From Asdrubali et al. (2015), PV power and geothermal power emerged as the renewable energy technologies with the highest overall environmental impacts. From the life cycle assessment conducted by Treyer and Bauer (2015) on kWh of electricity generated from different sources (natural gas, natural gas 
combined cycle, carbon capture and storage, European pressurized reactor, photovoltaics and concentrated solar power), a $\mathrm{kWh}$ of electricity generated from oil is associated with the highest environmental impacts; contribution to climate change, acidification and particulate matter formation. The relatively high environmental impact of a kWh of electricity generated from oil is associated with the impacts that occur within the fuel supply chain coupled with the low efficiency of the power plant that culminates in high emissions of particulate matter, $\mathrm{SO}_{2}, \mathrm{NO}_{\mathrm{x}}$ and greenhouse gases. Greenhouse gas emissions associated to the generation of electricity in Cameroon is estimated at $0.86 \mathrm{tCO}_{2} / \mathrm{MW}\left(860 \mathrm{gCO}_{2} / \mathrm{kWh}\right)$ (African Development Fund, 2009).

A kWh of electricity generated from a combined cycle natural gas plant was found to have a mean emission of $350-400 \mathrm{gCO}_{2 \mathrm{eq}} / \mathrm{kWh}$ while a hard coal plant with direct combustion has emission in the range of $750-1050 \mathrm{gCO}_{2 \mathrm{eq}} / \mathrm{kWh}$ (Turconi et al., 2013). The LCA emission for base load power plants powered by oil was found to be $530 \mathrm{gCO}_{2 \mathrm{eq}} / \mathrm{kWh}$ while that of peak load power plants was found to be in the range of 750 to $900 \mathrm{gCO}_{2 \mathrm{eq}} / \mathrm{kWh}$. The emission of a $\mathrm{kWh}$ of $\mathrm{PV}$ generated electricity $\left(162 \mathrm{gCO}_{2}\right)$ is lower compared to those from conventional power plants.

\section{Analysis and discussion of results}

\subsection{Results of PV system sizing}

Assuming a $15 \%$ efficiency of PV panels, the PV area for the required load is computed as $12.6 \mathrm{~m}^{2}, 22.7 \mathrm{~m}^{2}$ and $16.6 \mathrm{~m}^{2}$ for the T4, T5 and T6 building respectively. The detailed result of the sizing exercise is presented in Table 6 .

The power, area of PV modules and daily energy generated by the PV for T4, T5 and T6 were respectively determined as: $2103 \mathrm{~W}, 14 \mathrm{~m}^{2}$ and $9.8 \mathrm{kWh} /$ day; $3779 \mathrm{~W}, 25.2 \mathrm{~m}^{2}$ and 17.6 $\mathrm{kWh}$ /day; and $2766 \mathrm{~W}, 18.4 \mathrm{~m}^{2}$ and $12.9 \mathrm{kWh} /$ day.

Table 6: PV system sizing results for $\mathrm{T} 4, \mathrm{~T} 5$ and $\mathrm{T} 6$ building type

\begin{tabular}{|l|c|c|c|}
\hline PV components & $\mathrm{T} 4$ & $\mathrm{~T} 5$ & $\mathrm{~T} 6$ \\
\hline Array size & $14 \mathrm{~m}^{2}$ & $25.2 \mathrm{~m}^{2}$ & $18.4 \mathrm{~m}^{2}$ \\
\hline PV power & 2103 & 3779 & 2766 \\
\hline Number of modules & 9 & 15 & 11 \\
\hline Battery capacity (Ah) & 1680 & 3018 & 24 \\
\hline $\begin{array}{l}\text { Number of battery } \\
\text { (428A) }\end{array}$ & 16 & 28 & 114 \\
\hline $\begin{array}{l}\text { Capacity of charge } \\
\text { controller (A) }\end{array}$ & 93 & 156 & 826 \\
\hline $\begin{array}{l}\text { Capacity of inverter } \\
\text { (W) }\end{array}$ & 635 & 17.6 & 12.9 \\
\hline $\begin{array}{l}\text { Daily energy output } \\
\text { of PV (kWh/day) }\end{array}$ & 9.8 & & \\
\hline
\end{tabular}


A 250W BP monocrystalline solar PV module is selected for the residential stand-alone PV system (i.e. for T4, T5, and T6). The characteristic of the selected module is presented in Table 7.

Table 7. Characteristics of PV module

\begin{tabular}{|l|c|c|}
\hline \multicolumn{1}{|c|}{ Characteristic } & Rating & Unit \\
\hline Maximum Power, $P_{\max }$ & 250 & $\mathrm{~W}$ \\
\hline Optimum Power Voltage & 30.1 & $\mathrm{~V}$ \\
\hline Optimum Operating Current & 8.355 & $\mathrm{~A}$ \\
\hline Open Circuit Voltage, $V_{O C}$ & 37.7 & $\mathrm{~V}$ \\
\hline Short Circuit Current, $I_{S C}$ & 8.788 & $\mathrm{~A}$ \\
\hline
\end{tabular}

A total of 9, 15 and 11 modules of $250 \mathrm{~W}_{\mathrm{p}}$ each are required to meet the load of the T4, T5 and $\mathrm{T} 6$ building respectively. Based on the required DC bus voltage, the series and parallel configuration of the array can be adjusted accordingly. The required capacity of the battery was computed to be $4032 \mathrm{Wh}, 72433 \mathrm{Wh}$ and 53 017Wh for T4, T5 and T6 respectively. Based on the DC bus voltage of 24, the required battery capacity is calculated to be $1680 \mathrm{Ah}$, 3 018Ah, and $2209 \mathrm{~A}$ h for T4, T5 and T6 respectively.

\subsection{Life cycle cost analysis of the PV system}

The PV array cost is calculated to be $€ 4500, € 7500$ and $€ 5500$ for T4, T5 and T6 respectively while the capital cost of the initial set of batteries was calculated to be $€ 4200, € 7$ 545 and $€ 5522$ for T4, T5 and T6 respectively. The present worth of the first set of batteries replaced after 10 years and the second set of batteries replaced after 20 years was respectively calculated as: $€ 2637$ and $€ 1656$; $€ 4738$ and $€ 2$ 975; and $€ 3468$ and $€ 2178$ for T4, T5 and T6 respectively. The installation cost of the PV-system was taken as $10 \%$ of the capital cost of the PV modules and this was calculated to be $€ 450, € 750$ and $€ 550$ for T4, T5 and T6 respectively. The present worth of the maintenance cost taken as $2 \%$ of the initial cost of the PV modules was computed to be $€ 1299$, $€ 2165$ and $€ 1588$ for T4, T5 and T6 respectively. The costs of the inverter and charge controller were respectively obtained as: $€ 158$ and $€ 812$; $€ 198$ and $€ 1$ 353; and $€ 206$ and $€ 992$ for T4, T5 and T6 respectively. The life cycle cost of the PV-system for T4, T5 and T6 computed as the present worth of the cost of all the system components including installation and maintenance cost are $€ 15714, € 27$ 227and $€ 20006$ respectively. The ALCC of the system for T4, T5 and T6 were calculated to be $€ 1039, € 1$ 800 and $€ 1322$ respectively.

Table 8: Summary of cost and results of economic analysis

\begin{tabular}{|l|c|c|c|}
\hline Component & T4 & T5 & T6 \\
\hline PV array cost & $€ 4500$ & $€ 7500$ & $€ 5500$ \\
\hline Installation cost & $€ 450$ & $€ 750$ & $€ 550$ \\
\hline Cost of inverter & $€ 158$ & $€ 198$ & $€ 206$ \\
\hline Cost of charge controller & $€ 812$ & $€ 1353$ & $€ 992$ \\
\hline Present worth of maintenance cost & $€ 1299$ & $€ 2165$ & $€ 1588$ \\
\hline
\end{tabular}




\begin{tabular}{|l|c|c|c|}
\hline LCC & $€ 5714$ & $€ 27227$ & $€ 20006$ \\
\hline ALCC & $€ 1039$ & $€ 1800$ & $€ 1322$ \\
\hline Unit cost of electricity $(€ \mathrm{c} / \mathrm{kWh})$ & 52 & 50 & 51 \\
\hline
\end{tabular}

The average unit cost of electricity generated by the systems was obtained as $€ 0.52 / \mathrm{kWh}$, $€ 0.50 / \mathrm{kWh}$, and $€ 0.51 / \mathrm{kWh}$ for T4, T5 and T6 respectively. The unit cost of PV generated electricity in Cameroon obtained for the different building types from this study is quite high compared to: $12.5 € \mathrm{c} / \mathrm{kWh}\left(\mathrm{PKR} 14.8 \mathrm{kWh}^{-1}\right.$ ) obtained for a tropical region in Pakistan (Abdul and Anjum, 2015); €c13/kWh (Rs. $9.56 \mathrm{kWh}^{-1}$ ) obtained for Bangalore, India (Ghosh et al., 2015); €c24(27 USc) obtained for Kenya (Ondraczek, 2014); and $€ \mathrm{c} 15.7$ (0.7 R\$) to $€ \mathrm{c} 21.1$ $/ \mathrm{kWh}$ (R\$ 0.94) obtained for Brazil (Miranda et al., 2015). The high unit cost of PV generated electricity in Cameroon could be associated to the high cost of solar PV modules (Mbaka et al., 2010).

It is worthy of note that the current tariff for grid electricity supplied to the residential sector in the country is $€ \mathrm{c} 12 \mathrm{kWh}^{-1}$ (79 CFA/kWh). Hence, from an economic perspective, the residential PV system is less competitive to the electricity supplied to dwellings from the grid. The less competitiveness on the part of the solar PV-system irrespective of the country's solar potentials could be explained by the fact that government policies over the years to boost the quantity of electricity generated have largely been concentrated on hydro and thermal power plants (Ayompe and Duffy, 2014). Studies by Ayompe and Duffy (2014) revealed a levelized cost of PV generated electricity in Cameroon in the order of $6.79 € \mathrm{c} / \mathrm{kWh}$ to $28.82 € \mathrm{c} / \mathrm{kWh}$, which is lower compared to the unit electrical cost obtained for this study. This is not unexpected since Ayompe and Duffy (2014) assumed that electricity generated by the PV system will be used on-site in the installed premises with shortfalls imported from the grid. Consequently, a battery backup system was not considered in the PV-system design as opposed to the stand-alone PV system design with battery backup considered in our study.

\subsection{Environment impacts from T4, T5 and T6 buildings}

Using equation 10, the emission savings associated with the use of a $\mathrm{kWh}$ of PV generated electricity in Cameroon was obtained as $698 \mathrm{gCO}_{2}$. The total daily emission savings associated with the use of PV generated electricity in our T4, T5 and T6 case study buildings were obtained as $3769.2 \mathrm{gCO}_{2}, 6770.6 \mathrm{gCO}_{2}$, and $4955.8 \mathrm{gCO}_{2}$ respectively.

\section{Conclusion}

The focus of this study was on assessing the feasibility of PV-systems in meeting the required load of three typical residential dwellings in Yaoundé, Cameroon. The study encompasses the algorithm for the sizing of the entire PV system, peak power of array, size of battery bank, size of inverter and charge controller required to meet the daily electrical load of the building under study. Based on the results, the PV power, area of PV modules and daily energy generated by the PV for T4, T5 and T6 were respectively determined as $2103 \mathrm{~W}, 14 \mathrm{~m}^{2}$ and $9.8 \mathrm{kWh} /$ day; $3779 \mathrm{~W}, 25.2 \mathrm{~m}^{2}$ and $17.6 \mathrm{kWh} /$ day; and $2766 \mathrm{~W}, 18.4 \mathrm{~m}^{2}$ and $12.9 \mathrm{kWh} /$ day. The battery bank capacity, size of inverter and controller were respectively obtained as: 40 
$323 \mathrm{Wh}, 635 \mathrm{~W}$ and $93 \mathrm{~A}$ for T4; $72433 \mathrm{Wh}, 795 \mathrm{~W}$ and 156A for T5; and $53017 \mathrm{Wh}, 826 \mathrm{~W}$ and 114A for T6. The life cycle cost analysis method was employed for the economic analysis so as to determine the economic feasibility of the system to the users. Results of the economic analysis revealed a life cycle cost of the system for T4, T5 and T6 to be $€ 15714$, $€ 27227$, and €20 006 respectively while the annualized LCC for T4, T5 and T6 were respectively obtained as $€ 1039, € 1800$ and $€ 1322$. The average unit cost of electricity was obtained as $€ 0.52 \mathrm{~kW} \mathrm{~h}^{-1}, € 0.50 \mathrm{~kW} \mathrm{~h}^{-1}$ and $€ 0.51 \mathrm{~kW} \mathrm{~h}^{-1}$ for T4, T5 and T6 respectively. The results revealed that the average unit price of a stand-alone PV generated electricity in Yaoundé, Cameroon is higher than that of the conventional grid electricity supply to the residential sector in the country. To appreciate the findings of this study, results from other studies will be discussed. Okoye et al. (2016) computed the unit cost of energy generated from a PV-system in Onitsha in Nigeria to be $0.502 \mathrm{USDkWh}^{-1}\left(0.45 € \mathrm{~kW} \mathrm{~h}{ }^{-1}\right)$ while a similar study in Sokoto, yielded to be $0.62 \mathrm{USD} \mathrm{kW} \mathrm{h}^{-1}\left(0.56 € \mathrm{~kW} \mathrm{~h}^{-1}\right)$ at current conversion rate of $1 \mathrm{USD}=0.9 €$. Thus, the average unit energy cost T4, T5 and T6 are more expensive than in Onitsha and cheaper than in Sokoto. This comparison supports the fact that the unit energy values of T4, T5 and T6 are within acceptable values. The use of a kWh of electricity generated by the PV system in our case studies impacts positively on the environment by avoiding the emission of $698 \mathrm{gCO}_{2}$.

The energy consumption in T5 is greater than that of T6, despite the former having a smaller floor area than the latter. This is because T5 contains appliances (e.g. fridge ) with very high power rating than T6. Also, as earlier alluded to in section 4.1 and Manjia et al. (2015), houses in Cameroon do not contain standard pre-installed household appliances like in developed countries. Consequently, it is not so straightforward to compare household energy consumption based on the gross floor areas of buildings in Cameroon. It is not uncommon to find same appliances from disparate sources including importing used appliances in homes with very different power ratings. As part of future research, a detail study of the different energy consumption pattern and important parameters such as gross floor area and number of households in selected towns in Cameroon will be conducted. This will provide insights for comparing the energy performance of different houses in relation to other parameters including gross floor areas.

\section{References}

Abanda, F.H. (2012) Renewable energy sources in Cameroon: Potentials, benefits and enabling environment. Renewable and Sustainable Energy Reviews, Vol. 16 (7), pp. 4557 4562 .

Abanda, H., Ng'ombe, A., Tah, J. H. M. and Keivani, R. (2012). The link between renewable energy production and Gross Domestic Product in Africa: A comparative study between 1980-2008. Renewable and Sustainable Energy Reviews. Vol. 16 (4), pp. 2147-2153.

Abdul, G. and Anjum, M. (2015). Design and economics analysis of an off-grid PV system for household electrification. Renewable and Sustainable Energy Reviews, Vol. 42, pp.496502. 
Africa-EU energy Partnership (undated). Country power market brief: Cameroon. [Online] http://www.euei-

pdf.org/sites/default/files/field_publication_file/Cameroon_Power_Sector_Market_Brief_Dec 2013 EN.pdf [July 2016].

African Development Fund (2009). Project to strengthen and extend the electricity transmission and distribution networks in the Republic of Cameroon. Appraisal report. Available at: <http://www.afdb.org/fileadmin/uploads/afdb/Documents/Project-andOperations/-\%20Cameroon\%20-\%20AR\%20Electricity\%20Project\%20-\%5B1\%5D.pdf>

Ajan, C. W., Ahmed, S. S., Ahmed, H. B., Taha, F. and Zin, A. A. B. M. (2003). On the policy of photovoltaic and diesel generation mix for an off-grid site: East Malaysian perspectives. Solar Energy, Vol. 74, 453-467.

Ang B.W., Choong W.L. and Ng T.S. (2015) Energy security: Definitions, dimensions and indexes. Renewable and Sustainable Energy Reviews, Vol. 42, pp. 1077-1093.

Asdrubali, F., Baldinelli, G., D’Alessandro, F., and Scrucca, F. (2015). Life cycle assessment of electricity production from renewable energies: Review and results harmonization.

Renewable and Sustainable Energy Reviews, Vol.42, pp.1113-1122.

Ayompe, L. M. and Duffy, A. (2014). An assessment of the energy generation potential of photovoltaic systems in Cameroon using satellite-derived solar radiation datasets. Sustainable Energy Technologies and Assessments, Vol. 7, 257-264.

Birajdar P., Bammani S., Shete A., Bhandari R. and Metan S. (2013) Assessing the technical and economic feasibility of a stand-alone PV-system for rural electrification: A case study. International Journal of Engineering Research and Applications, Vol. 3(4), pp. 2525-2529.

Baurzhan, S., and Jenkins, G. P. (2016). Off-grid solar PV: Is it an affordable or appropriate solution for rural electrification in Sub-Saharan African countries? Renewable and Sustainable Energy Reviews, 60, 1405-1418.

Bouabdallah, A., Olivier, J.C., Bourguet, S., Machmoum, M. and Schaeffer E. (2015). Safe sizing methodology applied to a standalone photovoltaic system. Renewable Energy, Vol.80, pp.266-274.

CAHF (2015) Housing finance in Africa: A review of some of Africa's housing finance markets. Centre for Affordable Housing Finance in Africa, South Africa.

Caisheng, W. and Nehrir, M. H. (2008). Power management of a stand-alone wind/photovoltaic/fuel cell energy system. IEEE Transactions on Energy Conversion, Vol. 23(3), pp.957- 967.

Celik, A. N. (2006). Present status of photovoltaic energy in turkey and life cycle technoeconomic analysis of a grid-connected photovoltaic house. Renewable and Sustainable Energy Reviews, Vol. 10, pp. 370-387.

Celik, A. N. (2007). Effect of different load profiles on the loss-of-load probability of standalone photovoltaic systems. Renewable Energy, Vol. 32, pp.2096-2115. 
Charman, K. (2010). Trashing the planet for natural gas: shale gas development threatens freshwater sources, likely escalates climate destabilization. Capitalism Nature Socialism, Vol. 21, pp.72-82.

Estiri, H. (2014). Building and household X-factors and energy consumption at the residential sector: A structural equation analysis of the effects of household and building characteristics on the annual energy consumption of US residential buildings. Energy Economics, Vol. 43, pp. 178-184.

European Union Energy Initiative Partnership Dialogue Facility (2014). National Energy Efficiency Policy, Strategy and Action Plan in the electricity sector in Cameroon.

Forster, P., Ramaswamy, V., Artaxo, P., Berntsen T., Betts, R., Fahey, D.W., Haywood, J., Lean, J., Lowe, D.C., Myhre, G., Nganga J., Prinn, R., Raga, G., Schulz, M., and Van Dorland, R. (2007). Changes in Atmospheric Constituents and in Radiative Forcing. In Solomon, S., D. Qin, M. Manning, Z. Chen, M. Marquis, K.B. Averyt, M. Tignor and H.L. Miller (Eds.), Climate Change 2007: The Physical Science Basis (pp. 130-234). Cambridge and New York: Cambridge University Press.

Fthenakis, V. M., Kim, H. C. and Alsema, E. (2008). Emissions from photovoltaic life cycles. Environmental Science \& Technology, Vol. 42(6), pp.2168-2174.

Ghosh, S., Nair, A. and Krishnan, S.S. (2015). Techno-economic review of rooftop photovoltaic systems: Case studies of industrial, residential and off-grid rooftops in Bangalore, Karnataka. Renewable and Sustainable Energy Reviews, Vol. 42, pp.1132-1142.

Girod, B., van Vuuren, D. P., and Hertwich, E. G. (2014). Climate policy through changing consumption choices: Options and obstacles for reducing greenhouse gas emissions. Global Environmental Change, Vol. 25, pp.5-15.

Government of Cameroon. (2013). Readiness Preparation Proposal Cameroon. Submitted to Forest Carbon partnership Facility (FCPF). Available online at: https://www.forestcarbonpartnership.org/cameroon.

Government of Cameroon. (2009). Growth and employment strategy paper. International Monetary Fund, Washington DC, USA.

Hernández, D. and Phillips, D. (2015). Benefit or burden? Perceptions of energy efficiency efforts among low-income housing residents in New York City. Energy Research and Social Science, Vol. 8, pp. 52-59.

IEA/NEA (2015) Projected costs of generating electricity. OECD, Paris. Retrieved from: http://www.oecdilibrary.org/docserver/download/6615071e.pdf?expires=1446595210\&id=id\&accname=guest \&checksum=79127E6043B2857D7FE141EA1251E52F.

International Energy Agency (IEA), 2015. Cameroon: Balances for 2012. Retrieved from http://www.iea.org/statistics/statisticssearch/report/?country=CAMEROON\&product=balanc es\&year $=2012$. 
IPCC. (2014). Summary for policymakers. In: Climate Change 2014: Mitigation of Climate Change. Contribution of Working Group III to the Fifth Assessment Report of the Intergovernmental Panel on Climate Change [Edenhofer, O., R. Pichs-Madruga, Y. Sokona, E. Farahani, S. Kadner, K. Seyboth, A. Adler, I. Baum, S. Brunner, P. Eickemeier, B. Kriemann, J. Savolainen, S. Schlomer, C. von Stechow, T. Zwickel and J.C. Minx (eds.)]. Cambridge University Press, Cambridge, United Kingdom and New York, NY, USA.

Kenfack, J., Fogue, M., Hamandjoda, O., and Tatietse, T. T. (2011). Promoting renewable energy and energy efficiency in Central Africa: Cameroon case study. In: "World Renewable Energy Congress, 8-13 May, 2011, Linkoping, Sweden.

Lillo, Pau, Ferrer-Martí, Laia, Boni, A., and Fernández-Baldor, Á. (2015). Assessing management models for off-grid renewable energy electrification projects using the Human Development approach: Case study in Peru. Energy for Sustainable Development, Vol. 25, pp.17-26.

Ma, T., Yang, H., Lu, L., and Peng, J. (2015). Pumped storage-based standalone photovoltaic power generation system: Modeling and techno-economic optimization. Applied Energy, Vol. 137, pp. 649-659.

Maatallah, T., Ghodhbane, N. and Nasrallah, S. B. (2016). Assessment viability for hybrid energy system (PV/wind/diesel) with storage in the northernmost city in Africa, Bizerte, Tunisia. Renewable and Sustainable Energy Reviews, 59, 1639-1652.

Manjia, M.B., Abanda, F.H and Pettang, C. (2015). Household energy appliances in Cameroon. Environmental Management and Sustainable Development, Vol. 4(1), pp. 73-84.

Mbaka, N. E., Mucho, N. J. and Godpromesse, K. (2010). Economic evaluation of smallscale photovoltaic hybrid systems for mini-grid applications in far north Cameroon. Renewable Energy, Vol. 35(10), pp. 2391-2398.

Mboumboue E. and Njomo D. (2016) Potential contribution of renewables to the improvement of living conditions of poor rural households in developing countries: Cameroon's case study. Renewable and Sustainable Energy Reviews, Vol. 61, pp. 266-279.

Miranda, R. F.C., Szklo, A. and Schaeffer, R. (2015). Technical-economic potential of PV systems on Brazilian rooftops. Renewable Energy, Vol. 75, pp. 694-713.

Nfah, E. M. (2013). Evaluation of optimal photovoltaic hybrid systems for remote villages in Far North Cameroon. Renewable Energy, 51, pp. 482-488.

Nfah E.M. and Ngundam J.M. (2012) Identification of stakeholders for sustainable renewable energy applications in Cameroon. Renewable and Sustainable Energy Reviews, Vol. 16(7), pp. 4661-4666.

Nfah, E. M. and Ngundam, J. M. (2009). Feasibility of pico-hydro and photovoltaic hybrid power systems for remote villages in Cameroon. Renewable Energy, Vol.34 (6), pp.14451450 . 
Nfah, E. M. and Ngundam, J .M. (2008). Modelling of wind/diesel/battery hybrid power systems for Far North Cameroon. Energy Conversion and Management, Vol. 49 (6), pp.1295-1301.

Nfah, E. M., Ngundam, J. M. and Tchinda, R. (2007). Modelling of solar/diesel/battery hybrid power systems for Far North Cameroon. Renewable Energy, Vol. 32 (4), pp. 832-844.

Novoselac, A., Cetin, K. S. and Tabares-Velasco, P. C. (2014). Appliance daily energy use in new residential buildings: Use profiles and variation in time-of-use. Energy and Buildings, Vol. 84, pp.716-726.

Ondraczek J. (2014). Are we there yet? Improving solar PV economics and power planning in developing countries: the case of Kenya. Renewable and Sustainable Energy Review, Vol. 30, pp. 604-615.

Ohijeagbon O.D. and Ajayi O.O. (2014) Potential and economic viability of standalone hybrid systems for a rural community of Sokoto, North-west Nigeria. Frontiers in Energy, Vol. 8(2), pp. 145-159.

Okoye C.O., Taylan O. and Baker D.K. (2016) Solar energy potentials in strategically located cities in Nigeria: Review, resource assessment and PV system design. Renewable and Sustainable Energy Reviews, Vol. 55, pp. 550-566.

Opiyo, N. (2016). A survey informed PV-based cost-effective electrification options for rural sub-Saharan Africa. Energy Policy, Vol. 91, pp. 1-11.

Oshaba, A. S., Ali E. S. and Abd-Elazim S. M. (2015) MPPT control design of PV system supplied SRM Using BAT search algorithm. Sustainable Energy, Grids and Networks, Vol. 2C, 2015, pp. 51-60.

Oshaba, A. S. and Ali E. S. (2014) Bacteria foraging: a new technique for speed control of DC series motor supplied by photovoltaic system. WSEAS Transactions on Power Systems, Vol. 9, 2014, pp. 185-195

Reddy, A. (2000). Energy and social issues. In: World Energy Council and UNEP, editors. Energy and the challenge of sustainability. New York, NY.

Rehman, S., Bader, M. A. and Al-Moallem, S. A. (2007). Cost of solar energy generated using PV panels. Renewable and Sustainable Energy Reviews, Vol. 11(8), pp. 1843-1857.

Rodrigues, S., Torabikalaki, R., Faria, F., Cafôfo, N., Chen, X., Ivaki, A. R., Mata-Lima H and Morgado-Dias, F. (2016). Economic feasibility analysis of small scale PV systems in different countries. Solar Energy, Vol. 131, pp. 81-95.

Saidi K. and Hammami S. (2015) The impact of energy consumption and $\mathrm{CO}_{2}$ emissions on economic growth: Fresh evidence from dynamic simultaneous-equations models.Sustainable Cities and Society, Vol. 14, pp. 178-186. 
Sandia National Laboratories (1995). Stand-alone photovoltaic systems-A handbook of recommended design practices. Photovoltaic Design Assistance Centre, Sandia National Laboratories, Albuquerque, New Mexico.

Shaahid S. and Elhadidy M. (2008). Economic analysis of hybrid photovoltaic-diesel battery power systems forresidential loads in hot regions - a step to clean future. Renewable and Sustainable Energy Review, Vol.12, pp.488-503.

Sherwani, A. F., Usmani, J. A., and Varun. (2010). Life cycle assessment of solar PV based electricity generation systems: A review. Renewable and Sustainable Energy Reviews, Vol. 14(1), pp. 540-544.

SIE-Cameroon, (2012). Situation énergétique du Cameroun rapport 2011. Ministère de l'eau et d'énergie, Yaoundé, Cameroun.

Tansi, B. N. (2011). An assessment of Cameroon's renewable energy resource and prospect for a sustainable economic development [MSc thesis]. Germany: Brandenburg Technical University.

Tchinda, R. and Kaptouom, E. (1999). Situation des energies nouvelles et renouvelables au Cameroun. Revue de l'Energie, 510 pp. 653-658.

Treyer, k. and Bauer, C. (2015). The environmental footprint of UAE's electricity sector: Combining life cycle assessment and scenario modeling. Renewable and Sustainable Energy Reviews, In press.

Turconi, R., Boldrin, A., and Astrup, T. (2013). Life cycle assessment (LCA) of electricity generation technologies: overview, comparability and limitations. Renewable and Sustainable Energy Reviews, Vol. 28, pp. 555-565.

United Nations Statistics Division (2015). Cameroon. Retrieved from http://data.un.org/Country Profile.aspx?crName=cameroon.

Ürge-Vorsatz, D., Cabezab, L. F., Serranob, S., Barrenecheb, C. and Petrichenkoa, K. (2015). Heating and cooling energy trends and drivers in buildings. Renewable and Sustainable Energy Reviews, Vol. 41, pp. 85-98.

Ürge-Vorsatz, D., Petrichenko K., Staniec, M. and Eom J. (2013). Energy use in buildings in a long-term perspective. Current Opinion in Environmental Sustainability, Vol. 5(2), pp.141151

Wenham, S. R, Green, M. A, and Watt, M. E. (1994). Applied photovoltaics. Australia: Center for Photovoltaic Devices and Systems.

Wirba A.V., Mas'ud A.A., Muhammad-Sukki F., Ahmad S., Tahar A.M., Rahim R.A., Munir A.B. and Karim M.E. (2015) Renewable energy potentials in Cameroon: Prospects and challenges. Renewable Energy,Vol. 76,pp. 560-565. 
Won, A. N. and W. H. Hong (2014). A survey on ownership of home appliances and electric energy consumption status according to the number of household member. Applied Mechanics and Materials, Vol. 672-674), pp. 2165-2168.

Yemene, S. (2009). Rapport d'étude sur le potentiel d'emplois de la filière des Infrastructures. Etude réalisée sur financement du BIT. Novembre 2008-Avril 2009, 153 p.

Zeman, M. (2012). Photovoltaic systems. Solar Cells, 1-9. Retrieved from: http://ocw.tudelft.nl/fileadmin/ocw/courses/SolarCells/res00029/CH9 Photovoltaic systems. $\underline{\mathrm{pdf}}$

Zubi, G., Dufo-López, R., Pasaoglu, G. and Pardo, N. (2016). Techno-economic assessment of an off-grid PV system for developing regions to provide electricity for basic domestic needs: A 2020-2040 scenario. Applied Energy, 176, 309-319. 
Appendix I: Model for PV system sizing (T6 building)

Table 9: Sizing of the array

\begin{tabular}{|c|c|c|c|c|c|c|c|c|c|c|c|c|c|c|}
\hline $\begin{array}{l}\text { Lel } \\
(k W h)\end{array}$ & $\begin{array}{l}\mathbf{H}_{\mathrm{av}} \\
\mathrm{g}\end{array}$ & $\begin{array}{l}\text { np } \\
\text { v }\end{array}$ & nb & ni & $\begin{array}{l}\text { Tc } \\
\text { f }\end{array}$ & $\begin{array}{l}\text { Md } \\
\text { f }\end{array}$ & $\operatorname{Apv}\left(m^{2}\right)$ & $\begin{array}{l}\text { np } \\
\mathbf{v}\end{array}$ & $\begin{array}{l}\text { PV Energy } \\
\text { Output } \\
\text { (kWh/day) }\end{array}$ & $\begin{array}{l}\text { Sunshin } \\
\text { e } \\
\text { duratio } \\
\text { n } \\
\text { (h/day) }\end{array}$ & $\begin{array}{l}\text { PV Power } \\
\text { (W) }\end{array}$ & $\begin{array}{l}\text { Rating } \\
\text { of } \\
\text { selecte } \\
\text { d mod }\end{array}$ & $\begin{array}{l}\text { Number of } \\
\text { Mod }\end{array}$ & $\begin{array}{l}\text { Numbe } \\
\text { r of } \\
\text { Mod }\end{array}$ \\
\hline 7.1 & $\begin{array}{l}4.6 \\
6\end{array}$ & $\begin{array}{l}0.1 \\
5\end{array}$ & $\begin{array}{l}0.8 \\
5\end{array}$ & $\begin{array}{l}0 . \\
9\end{array}$ & 0.8 & 0.9 & $\begin{array}{l}=7.1 /(4.66 * 0.15 * 0.85 * 0.9 * \\
0.8) \\
=16.5 \\
\text { Adjusted area }=16.5 / 0.9= \\
18.4\end{array}$ & $\begin{array}{l}0.1 \\
5\end{array}$ & $\begin{array}{l}=18.4 * 0.15 * 4.66 \\
=12.9\end{array}$ & 4.66 & $\begin{array}{l}(12.9 / 4.66)^{*} 10 \\
00=2766\end{array}$ & 250 & $\begin{array}{l}=2766 / 250 \\
=11\end{array}$ & 11 \\
\hline
\end{tabular}

\begin{tabular}{|c|c|c|c|c|c|c|c|c|c|c|c|c|c|c|c|}
\hline \multicolumn{16}{|c|}{ Table 10: Sizing of battery bank } \\
\hline $\mathbf{N}_{\text {ced }}$ & Lel & nb & ni & Dd & Bsc & Bsc (Wh) & $\begin{array}{l}\text { DC bus } \\
\text { Voltage }\end{array}$ & BSc (Ah) & $\begin{array}{l}\text { Capacity } \\
\text { of } \\
\text { selected } \\
\text { Bat (Ah) }\end{array}$ & $\begin{array}{l}\text { Battery in } \\
\text { Parallel }\end{array}$ & $\begin{array}{l}\text { Battery } \\
\text { in } \\
\text { Parallel }\end{array}$ & $\begin{array}{l}\text { System } \\
\text { Nominal } \\
\text { V }\end{array}$ & $\begin{array}{l}\text { Battery } \\
\text { Nominal } \\
\text { V }\end{array}$ & $\begin{array}{l}\text { Bat } \\
\text { in } \\
\text { Series }\end{array}$ & $\begin{array}{l}\text { Total } \\
\text { Bat }\end{array}$ \\
\hline 4.57 & 7.1 & 0.85 & 0.9 & 0.8 & $\begin{array}{c}=4.57 * 7.1 /(0.85 * 0.9 * 0.8) \\
=53.01797\end{array}$ & $\begin{array}{c}=53.0179 * 1000 \\
=53017.97\end{array}$ & 24 & $\begin{array}{l}=53017.9 / 24 \\
=2209.082\end{array}$ & 428 & $\begin{array}{c}=2209.08 / 428 \\
=5.161407\end{array}$ & 6 & 24 & 6 & $\begin{array}{l}=24 / 6 \\
=4\end{array}$ & 24 \\
\hline
\end{tabular}

\begin{tabular}{|c|c|c|c|c|}
\hline \multicolumn{7}{|c|}{ Table 11: Sizing of the Charge controller } \\
\hline Factor & Module Current & Number of Modules & Array Current & Charge controller size \\
\hline 1.25 & 8.355 & 11 & $=8.15^{*} 11$ & $=1.25^{*} 81.5$ \\
& & & $=11.9$ & $=114$ \\
\hline
\end{tabular}

\begin{tabular}{|c|c|c|}
\hline \multicolumn{3}{|c|}{ Table 12: Sizing of the inverter } \\
\hline Expected AC power $(\mathbf{W})$ & $\mathbf{2 0 \%}$ excess & Inverter Size $(\mathbf{W})$ \\
\hline 688 & 1.2 & $=688 * 1.2$ \\
& & $=825.6$ \\
\hline
\end{tabular}

Where; Lel is the daily electrical load (in $\mathrm{kWh}$ ), Havg is the average daily solar insolation, npv is the efficiency of the PV module, nb and ni represents the battery efficiency and inverter efficiency respectively, Tcf is the temperature correction factor, Mdf is the module derate factor, Apv is the size of the PV array, Ip is the peak solar irradiance,

Nccd is the number of cloudy days, Dd is the depth of discharge and Bsc is the battery capacity. 
Appendix II: Life cycle cost analysis for T6

Table 13: LCC for the T6 solar PV system

\begin{tabular}{|c|c|c|c|c|c|c|c|c|c|}
\hline Years & $\begin{array}{l}\text { Mod } \\
\text { Cap } \\
\text { cost }\end{array}$ & $\begin{array}{c}\text { Initial } \\
\text { bat cost }\end{array}$ & $\begin{array}{c}\text { Bat rep } \\
\text { cost }\end{array}$ & $\begin{array}{c}\text { Charge } \\
\text { con } \\
\text { cost }\end{array}$ & $\begin{array}{c}\text { Inverter } \\
\text { cost }\end{array}$ & $\begin{array}{l}\text { Maintenance } \\
\text { cost } P W\end{array}$ & $\begin{array}{c}\text { Installation } \\
\text { cost }\end{array}$ & $\mathrm{LCC}$ & ALLC \\
\hline 1 & 5500 & 5522.75 & 0 & 992 & 206.5 & 0 & 550 & & \\
\hline 2 & 0 & 0 & 0 & 0 & 0 & 0 & 0 & & \\
\hline 3 & 0 & 0 & 0 & 0 & 0 & 0 & 0 & & \\
\hline 4 & 0 & 0 & 0 & 0 & 0 & 0 & 0 & & \\
\hline 5 & 0 & 0 & 0 & 0 & 0 & 0 & 0 & & \\
\hline 6 & 0 & 0 & 0 & 0 & 0 & 0 & 0 & & \\
\hline 7 & 0 & 0 & 0 & 0 & 0 & 0 & 0 & & \\
\hline 8 & 0 & 0 & 0 & 0 & 0 & 0 & 0 & & \\
\hline 9 & 0 & 0 & 0 & 0 & 0 & 0 & 0 & & \\
\hline 10 & 0 & 0 & 3468.33 & 0 & 0 & 0 & 0 & & \\
\hline 11 & 0 & 0 & 0 & 0 & 0 & 0 & 0 & & \\
\hline 12 & 0 & 0 & 0 & 0 & 0 & 0 & 0 & & \\
\hline 13 & 0 & 0 & 0 & 0 & 0 & 0 & 0 & & \\
\hline 14 & 0 & 0 & 0 & 0 & 0 & 0 & 0 & & \\
\hline 15 & 0 & 0 & 0 & 0 & 0 & 0 & 0 & & \\
\hline 16 & 0 & 0 & 0 & 0 & 0 & 0 & 0 & & \\
\hline 17 & 0 & 0 & 0 & 0 & 0 & 0 & 0 & & \\
\hline 18 & 0 & 0 & 0 & 0 & 0 & 0 & 0 & & \\
\hline 19 & 0 & 0 & 0 & 0 & 0 & 0 & 0 & & \\
\hline 20 & 0 & 0 & 2178.15 & 0 & 0 & 0 & 0 & & \\
\hline 21 & 0 & 0 & 0 & 0 & 0 & 0 & 0 & & \\
\hline 22 & 0 & 0 & 0 & 0 & 0 & 0 & 0 & & \\
\hline 23 & 0 & 0 & 0 & 0 & 0 & 0 & 0 & & \\
\hline 24 & 0 & 0 & 0 & 0 & 0 & 0 & 0 & & \\
\hline 25 & 0 & 0 & 0 & 0 & 0 & 1443.65 & 0 & & \\
\hline Total & 5500 & 5522.75 & 5646.48 & 992 & 206.5 & 1443.65 & 550 & 20006 & 1322 \\
\hline
\end{tabular}

Where:

$\mathrm{M}_{\mathrm{CC}}$ : Module capital cost

$\mathrm{I}_{\mathrm{BC}}$ : Initial battery cost

$\mathrm{C}_{\mathrm{BR}}$ : Battery replacement cost

$\mathrm{C}_{\mathrm{CC}}$ : Cost of charge controller

$\mathrm{C}_{\mathrm{i}}$ : Cost of inverter

$\mathrm{PW}_{\mathrm{MC}}$ : Present worth of maintenance cost

$\mathrm{C}_{\text {inst }}$ : Installation cost

LCC: life cycle cost

$\mathrm{U}_{\mathrm{el}}$ : Unit cost of electricity 


\section{APPENDIX III: Acronyms}

AC Alternating current

Ah Ampere hour

ALCC Annualized life cycle cost

CFA Communaute Française Africaine

$\mathrm{CO}_{2} \quad$ Carbon dioxide

DC Direct current

$\mathrm{gCO}_{2 \mathrm{eq}} \quad$ gram of carbon dioxide equivalent

GHG Greenhouse gas

GWh Gigawatt-hour

IPCC Intergovernmental Panel on Climate Change

Ktoe kilotonne of oil equivalent

kWh kilowatt-hour

LCA Life cycle assessment

LCC Life cycle cost

NASA National Aeronautics and Space Administration

NOx Oxides of nitrogen

NPV Net present value

PV Photovoltaic

PVHS photovoltaic hybrid systems

$\mathrm{SO}_{2} \quad$ Sulfur dioxide

$\mathrm{tCO}_{2} \quad$ tonnes of carbon dioxide

$\mathrm{UC}_{\mathrm{el}} \quad$ Unit cost of electricity

Wh watt-hour 